\title{
Developing Format of Clinical Pathway Using Nursing Diagnosis Based on Indonesian Nursing Diagnosis Standard \\ (Standar Diagnosis Keperawatan Indonesia: SDKI)
}

\author{
Sartika Wulandari \\ Faculty of Nursing, Universitas Airlangga \\ Surabaya, Indonesia \\ Sartika221284@gmail.com
}

\author{
Nursalam \\ Faculty of Nursing, Universitas Airlangga \\ Surabaya, Indonesia \\ nursalam@fkp.unair.ac.id \\ Eka Misbahatul M.Has \\ Faculty of Nursing, Universitas Airlangga \\ Surabaya, Indonesia \\ Eka.m.has@fkp.unair.ac.id
}

\begin{abstract}
Clinical Pathway is an integrated service planning concept that summarizes each step are given to patients according to the standard of service, the standard of nursing care, and other health personnel service standards, based on evidence with results that can be measured and within a certain period (Depkes, 2014). Problems that occur in the hospital, nurses do not know what should be included in the template of clinical pathways because they do not know what should be documented. Most of nurses just do and write as documentation from other professions e.g., (1) taking a blood sample, (2) access IV-line, (3) administered drugs (4) Catheterization, and (5) measure vital signs. The aim of this study was developing format of clinical pathway using standard nursing diagnosis based on Indonesian Nursing Diagnosis Standart (SDKI). Method of this study was analytical descriptive study that conducted to 50 health record for tracer study, 10 nurses at ward and 25 articles for literature review. The result showed that the appropriate nursing diagnosis based on SDKI for clinical pathway of Diabetic Mellitus were : unstable glucose level, activity intolerance, deficit of nutrition. For thrombotic Stroke were : decrease of adaptive intracranial capacity, physical mobility impairment, ineffective breathing pattern. For pneumonia were : ineffective airway clearance, activity intolerance, hyperthermia. For acute myocardial infarction were decreased of cardiac output, activity intolerance, spontaneous, circulation impairment. The next study will be good for issued not only diagnosis but also intervention on nursing
\end{abstract}

Keywords—clinical pathway; nursing diagnosis; SDKI

\section{INTRODUCTION}

The Commission on Accreditation of Hospitals (2012) decides that every hospital should consider that nursing care to be part of an integrated service system with other professionals (Doctor, Pharmacist, Nutritionist) as continuity services. All about services on each profession were documented in the care plan format namely Clinical Pathway [1]. Clinical Pathway is an integrated service planning concept that summarizes each step are given to patients according to the standard of service, the standard of nursing care, and other health personnel service standards, based on evidence with results that can be measured and within a certain period [2]. The format was developed to developing multidisciplinary (doctors, nurses, pharmacy, nutrition, rehabilitation and other health workers) that was created is not too complicated and lengthy based on evidence based on the results of a search of medical records of hospitalized patients during the last one year.

Previous study showed that the implementation of the Clinical Pathway increasing quality of care and patient safety [3]. As one component of the standard of nursing care is the Standart Nursing Language used in Indonesia, namely Standard Diagnosis Keperawatan Indonesia (SDKI), which was published on December 29th, 2016 [4]. It is expected to be a guideline nurses who have the authority as "enforcers diagnosis" in order to achieve improvement, prevention, healing and recovery of the client's health. Problems that occur in the hospital, nurses do not know what should be included in the template of clinical pathways because they do not know what should be documented. Most of nurses just do and write as documentation from other professions e.g: (1) taking a blood sample, (2) access IV-line, (3) administered drugs (4) Catheterization, and (5) measure vital signs. There are no nursing diagnosis in clinical pathways, the role of nurses more on mandates even in the nursing documentation (form separately) is already done documenting the SNL (Standardized Nursing Language) [4].

The aim of this study was developing format of clinical pathway using nursing diagnosis based on Indonesian Nursing Diagnosis Standart (SDKI). 


\section{METHOD}

This study was an analytical descriptive study that conducted to 50 health record for tracer study, 10 nurses at ward and 25 articles for literature review. Data were collected by tracer 50 health record by making a list from observing about sign and symptom of patients then make some nursing diagnosis based on Indonesian Nursing Diagnosis Standart (SDKI). This list was checked by medical doctor and specialist on separated Focus Group Discussion. The outcome from both of discussion was determine as clinical and expertise judgement for completing the result of this study

\section{RESULT}

Conducted 50 health records for tracing, 10 nurses for an interview and 25 studies from literature reviewing, and the result was :

Tabel 1 had informed that there is three nursing diagnosis of Diabetic Mellitus from tracing of 50 health records, the most of them was Unstable Glucose Level (100\%). It means that Unstable Glucose Level was favorable and suitable using by nurse at the hospital according to SDKI for patient with Diabetic Mellitus.

Tabel 2 had informed that there are 3 nursing diagnosis of Thrombotic Stroke from tracing of 50 health records, the most of them was Physical Mobility impairment (100\%). It means that Physical Mobility impairment was favorable and suitable using by nurse at hospital according to SDKI for patient with Thrombotic Stroke.

Table 1. Nursing diagnosis of Diabetic Mellitus from Health RECORD TRACER

Nursing Diagnosis (code) $\quad$ Frequency (\%)

\begin{tabular}{llc}
\hline 1. & Unstable Glucose Level (D.0027) & 100 \\
2. Activity intolerance (D.0056) & 85 \\
3. Risk of electrolyte imbalance & 45 \\
(D.0037) & \\
\hline
\end{tabular}

TABle 2. Nursing diagnosis of Thrombotic Stroke from Health RECORD TRACER Nursing Diagnosis (code) $\quad$ Frequency (\%)

1. Decrease of adaptive intracranial

80 capacity (D.0066)

2. Physical Mobility Impairment (D.0056)

100

3. Ineffective Breathing Pattern (D.0005) 70

TABLE 3. NURSING DIAGNOSIS OF PNEUMONIA FROM HR TRACER Nursing Diagnosis (code) $\quad$ Frequency (\%)

\begin{tabular}{lll} 
1. Ineffective Airway Clearance (D.0005) & 80 \\
2. Activity intolerance (D.0056) & 100 \\
3. Ineffective Breathing Pattern (D.0005) & 100 \\
\hline
\end{tabular}

Tabel 3 had informed that there are 3 nursing diagnosis of Pneumonia from tracing of 50 health records, the most of them was Activity intolerance $(100 \%)$ and Ineffective Breathing Pattern (100\%).It means that Activity intolerance and Ineffective Breathing Pattern was favorable and suitable using by nurse at hospital according to SDKI for patient with Pneumonia.

Tabel 4 had informed that there are three nursing diagnosis of Pneumonia from tracing of 50 health records, the most of them was Decrease of Cardiac output (100\%) and Ineffective Breathing Pattern (100\%). It means that Decrease of Cardiac output and Ineffective Breathing Pattern was favorable and suitable using by nurse at hospital according to SDKI for patient with Acute Myocardial Infarction.

TABLE 4. NURSING DIAGNOSIS OF ACUTE MYOCARDIAL INFARCTION FROM HEALTH RECORD TRACER

Nursing Diagnosis (code)

Frequency $(\%)$

1. Activity intolerance (D.0056) 100

2. Decrease of Cardiac output (D.0056) 100

3. Ineffective Breathing Pattern (D.0005) 70

TABLE 5. LIST OF ADDING NURSING DIAGNOSIS FROM INTERVIEW WITH 10 NURSES ON ALL CASE

\begin{tabular}{lcc}
\multicolumn{1}{c}{ Case } & \multicolumn{1}{c}{ Nursing Diagnosis (code) } & $\begin{array}{c}\text { Freq } \\
(\%)\end{array}$ \\
\hline Diabetic Mellitus & $\begin{array}{l}\text { 1.Skin integrity disturbance } \\
(\text { D.0129) } \\
\text { 2.Deficit of nutrition (D.0019) }\end{array}$ & 20 \\
Thrombotic & \multicolumn{1}{c}{ n.a } \\
$\begin{array}{l}\text { Stroke } \\
\text { Pneumonia } \\
\text { Acute Myocardial } \\
\text { Infarction }\end{array}$ & $\begin{array}{l}\text { 1.Hyperthermia (D.0130) } \\
\text { 1.Acute Pain (D.0077) }\end{array}$ & n.a \\
& $\begin{array}{l}\text { 2.Ineffective Myocard perfusion } \\
\text { (D.0014) }\end{array}$ & 70 \\
\hline
\end{tabular}

TABLE 6. LIST OF ADDING NURSING DIAGNOSIS FROM LITERATURE REVIEW (25 STUDIES) ON ALL CASE

\begin{tabular}{|c|c|}
\hline Case & $\begin{array}{c}\text { Nursing Diagnosis } \\
\text { NANDA = SDKI (code) }\end{array}$ \\
\hline $\begin{array}{l}\text { Diabetic } \\
\text { Mellitus }\end{array}$ & $\begin{array}{l}\text { 1. Impaired Skin Integrity = skin integrity } \\
\text { disturbance (D.0129) } \\
\text { 2. Risk for activity intolerance = Activity intolerance } \\
\text { (D.0056) } \\
\text { 3. Imbalance nutrition : less than body requirement = } \\
\text { Deficit of nutrition (D.0019) }\end{array}$ \\
\hline $\begin{array}{l}\text { Thrombotic } \\
\text { Stroke }\end{array}$ & $\begin{array}{l}\text { 1. Impaired physical mobility = Physical mobility } \\
\text { impairment (D.0056) } \\
\text { 2. Decreased intracranial adaptive capacity }(7,7 \%)= \\
\text { decreased of adaptive intracranial capacity (D.0056) }\end{array}$ \\
\hline Pneumonia & $\begin{array}{l}\text { 1. Ineffective breathing pattern = Ineffective } \\
\text { breathing pattern (D.0005) } \\
\text { 2. Altered body temperature = hyperthermia (D.0130) }\end{array}$ \\
\hline
\end{tabular}




$\begin{array}{lr}\text { Acute } & \text { 1.Reduced cardiac output = Decreased of cardiac } \\ \text { Myocardial } & \text { output (D.0005) } \\ \text { Infarction } & \text { 2.Spontaneous Circulation impairment (D.0007) }\end{array}$

Tabel 6 had informed that there are nine new nursing diagnosis from literature review using 25 studies on all case (Diabetic Mellitus, Thrombotic Stroke, Pneumonia, Acute Myocardial Infarction).

\section{DISCUSSION}

Tracing to 50 health records, there are three nursing diagnosis on patient diabetes mellitus, and the most of them was unstable glucose level $(100 \%)$ based on their sign and symptom. It means that unstable glucose level was suitable using by nurse at hospital according to SDKI for patient with diabetic mellitus. From interview to 10 nurses on patient with diabetic Mellitus, there are 2 new nursing diagnosis : skin integrity disturbance and deficit of nutrition. It was relevant with previous study that nursing diagnosis for patient with diabetic mellitus was risk for activity intolerance, imbalance nutrition, and less than body requirement [5]. According to SDKI, most of nursing diagnosis was on category : physiology [4]

Thrombotic Stroke, have 3 nursing diagnosis after tracing to 50 health records, the most of them was physical mobility impairment (100\%). Finds one major nursing diagnosis in patients with cerebrovascular disease was impaired physical mobility [6]. It means that Physical Mobility impairment was appropriate using by nurse at hospital according to SDKI for patient with thrombotic stroke. According to SDKI, most of nursing diagnosis was on category : physiology [4].

According to SDKI, most of nursing diagnosis patient with Pneumonia was on category : physiology [4]. There are 3 nursing diagnosis of Pneumonia from tracing of 50 health records, the most of them was activity intolerance $(100 \%)$ and Ineffective Breathing Pattern (100\%). It means that Activity intolerance and Ineffective Breathing Pattern was favorable and suitable using by nurse at hospital according to SDKI for patient with Pneumonia. Top 2 nursing diagnosis of the patient on 3 hospitals with almost 1000 beds was activity intolerance and Ineffective Breathing Pattern (100\%) [7].

The most nursing problem patient with acute myocardial infarction was reduce cardiac output [8]. Tabel 4 had informed that there is three nursing diagnosis of Pneumonia from tracing of 50 health records, the most of them was decrease of cardiac output $(100 \%)$ and Ineffective Breathing Pattern (100\%). It means that decrease of cardiac output and ineffective breathing pattern was favorable and suitable using by nurse at hospital according to SDKI for patient with acute myocardial infarction.

\section{CONCLUSION}

The Appropriate Nursing Diagnosis based on SDKI for Diabetic Mellitus were : (1).Unstable Glucose Level (D.0027), (2).Activity intolerance (D.0056), (3).Risk of electrolyte imbalance (D.0037), (4).Skin integrity disturbance (D.0129), (5).Deficit of nutrition (D.0019)

The Appropriate Nursing Diagnosis based on SDKI for Thrombotic Stroke were : (1). Decrease of adaptive intracranial capacity (D.0066), (2). Physical Mobility Impairment (D.0056) (3). Ineffective Breathing Pattern (D.0005)

The Appropriate Nursing Diagnosis based on SDKI for Pneumonia were : (1). Ineffective Airway Clearance (D.0005), (2). Activity intolerance (D.0056) (3). Ineffective Breathing Pattern (D.0005), (4). Hyperthermia (D.0130)

The Appropriate Nursing Diagnosis based on SDKI for Acute Myocardial Infarction were : (1). Decreased of cardiac output (D.0005) (2). Activity intolerance (D.0056) (3). Ineffective Breathing Pattern (D.0005), (4) Spontaneous Circulation impairment (D.0007) (5) Acute Pain (D.0077)

\section{REFERENCES}

[1] H. Permana, XXI Hal Penting Penyusunan Clinical Pathway. Bandung: Pusat Informasi Ilmiah FK Unpad, 2016

[2] Departemen Kesehatan, Buku Panduan Pelaksanaan Clinical Pathway. Jakarta: Depkes, 2014

[3] W. Mater and R. Ibrahim, "FACTORS SUPPORTING TEAMWORK COMMUNICATION IN CLINICAL PATHWAYS: SYSTEMATIC LITERATURE REVIEW," J. Theor. Appl. Inf. Technol., vol. 3081, no. 3,2015

[4] Persatuan Perawat Nasional Indonesia, Standar Diagnosis Keperawatan Indonesia. Jakarta: PPNI, 2016.

[5] C. Minthorn and M. Lunney, "Participant action research with bedside nurses to identify NANDA-International, Nursing Interventions Classification, and Nursing Outcomes Classification categories for hospitalized persons with diabetes," Appl. Nurs. Res., vol. 25, no. 2, pp. 75-80, May 2012.

[6] A. C. M. A. C. C. Lima et al., "Nursing Diagnosis in Patients with Cerebral Vascular Accident: an Integrative Review," Rev. Bras. Enferm., vol. 69, no. 4, pp. 785-792, Aug. 2016.

[7] C. Hogan, M. Barry, M. Burke, and P. Joyce, "Healthcare professionals" experiences of the implementation of integrated care pathways," Int. J. Health Care Qual. Assur., vol. 24, no. 5, pp. 334-347, Jun. 2011.

[8] Ana cavalcanti and juliana pereira, "nursing diagnoses of patients with heart failure: an integrative review," online brazilian J. Nurs., vol. 13, no. 1 , pp. 113-125, 2014 